\title{
The Dual Therapeutic Effect Of Metformin Nuclei Based Drugs Modified With One Of Tulbaghia Violacea Extract Compounds
}

Safaa S Hassan ( $\sim$ hsafaa@sci.edu.cu.eg )

Cairo University

Elaria A Bedir

Cairo University

Abd El-Rahman M Hamza

Cairo University

Ahmed M Ahmed

Cairo University

Nouran M Ibrahim

Cairo University

Mahmoud S Abd El-Ghany

Cairo University

Nada N Sayed

Cairo University

Bassant M Eimera

Cairo University

Mabrouk Salama

University of Benghazi

Eman F. Mohamed

Al-Azhar University

Dalia B Mohamed

National Research Centre

\section{Research Article}

Keywords: Vanadium (IV) and platinum (II) complexes, tyrosine kinase, Metformin, COVID-9 virus.

Posted Date: February 9th, 2022

DOI: https://doi.org/10.21203/rs.3.rs-1334983/v1 
License: (c) (i) This work is licensed under a Creative Commons Attribution 4.0 International License. Read Full License 
The dual therapeutic effect of metformin nuclei based drugs modified with one of Tulbaghia violacea extract compounds

Safaa S Hassan ${ }^{*}$,Elaria A Bedir ${ }^{2}$,Abd El-Rahman M Hamza'2,Ahmed M Ahmed²,Nouran M Ibrahim $^{2}$,Mahmoud S Abd El-Ghany ${ }^{2}$, Nada N Sayed ${ }^{2}$, Bassant M Eimera $^{2}$, Mabrouk Salama $^{3}$, Eman F. Mohamed ${ }^{4}$ and Dalia B Mohamed ${ }^{5}$

${ }^{1}$ Department of chemistry, Faculty of Science, Cairo University, Giza, Egypt

${ }^{2}$ Department of biotechnology, Faculty of Science, Cairo University, Giza, Egypt

${ }^{3}$ Department of Chemistry, Faculty of Science, University of Benghazi, Benghazi, Libya

${ }^{4}$ Department of chemistry, Faculty of Science (Girls), Al-Azhar University, Nasr City, Egypt

${ }^{5}$ Department of Therapeutic Chemistry, National Research Centre, Cairo, Egypt

$\underline{\text { Safaa_inorgchem@yahoo.com, hsafaa@sci.cu.edu.eg }}$

\begin{abstract}
Novel Schiff base was synthesized from condensation reaction of metformin with [4(Diethylamino) benzaldehyde (NBM). Different metal complexes were prepared using Pd(II), Pt(II), $\mathrm{Cu}$ (II) and V(IV) metal ions. All complexes showed the non-electrolytic behavior. So, the expected molecular formulas for complexes are $\left[\mathrm{Pd}(\mathrm{NBM}) \mathrm{Cl}_{2}\right], \quad\left[\mathrm{Pt}(\mathrm{NBM}) \mathrm{Cl}_{2}\right], \quad\left[\mathrm{Cu}(\mathrm{NBM})_{2} \mathrm{Cl}_{2}\right]$ and $\left[\mathrm{VO}(\mathrm{NBM})_{2}\right]$.

The cytotoxicity of (NBM) Schiff base and its metal complexes on human cancer cell line, MCF-7, was investigated. $\mathrm{V}$ (IV) and $\mathrm{Cu}$ (II) complexes showed potential blood-glucose lowering effect higher than the commercial metformin drug. VO(IV) complex has superior antioxidant activity more than the other synthesized compounds and the standard ascorbic acid. Molecular docking investigation proved the presence of interesting interactions between all synthesized compounds with the active site amino acids of EGFR tyrosine kinase (anticancer activity). The molecular docking of metal complexes observed effective inhibition for the specific mTOR protein that is expected to aid the growth of the COVID-19 virus.
\end{abstract}

Keywords: Vanadium (IV) and platinum (II) complexes, tyrosine kinase, Metformin, COVID-9 virus. 


\section{Introduction}

Metformin, an antidiabetic inexpensive drug. In 1995, Metformin was approved by the Food and Drug Administration (FDA) as an oral hypoglycemic agent. Recently, several studies reported[1,2] the potential efficacy of metformin as a promising drug for treating polycystic ovary syndrome, cancer, aging, cardiovascular diseases, metabolic syndrome, and neurological diseases. In addition, it is used off-label for weight reduction in the USA [3]. Recent evidence pointed out novel behaviors of metformin in the treatment of reduced macrophage cytokines synthesis and autoimmune disease [3]. Also, it may have an inhibitory effect on the virus, through increasing insulin sensitivity [4]. (Diethylamino)benzaldehyde was identified in GC-MS analysis of Tulbaghia violacea extract (TVL), Data obtained demonstrated the hypoglycemic effects of TVL in STZ-induced diabetic rats [5]. The most effective metal ions used are chromium, manganese, copper, cobalt, zinc and vanadium. So, it is expected that Schiff bases produced from the condensation between metformin drug and 4-(Diethylamino)benzaldehyde will be effective hypoglycemic drugs specially when form complexes. Cisplatin is one of the most widely used anticancer drugs [6,7] and highly effective in the treatment of testicular and ovarian cancer. Therefore, complexes like cisplatin which were formed using the previous synthesized Schiff bases with platinum (II) and palladium (II) ions expected to have powerful antitumor effect [8-11]. 'Metformin in COVID-19: A possible role beyond diabetes'. Because it was discovered that metformin not only has immunomodulatory and antiviral activities but also prevents various acute lung injuries in animal models [3, 12].

So, the present work aims to study, the synthesis of novel Schiff base derived from metformin with Diethylamino)benzaldehyde and its different metal complexes specially $\mathrm{Pt}(\mathrm{II})$ and $\mathrm{V}(\mathrm{IV})$ in many bio-application fields as antidiabetics, antitumor, antioxidant and finally their molecular docking as antiviral against COVID-19.

\section{Experimental}

\subsection{Materials and Reagents}

4-(Diethylamino)benzaldehyde, Metal chloride salts [platinum (II), palladium \& copper (II)], vanadyl (IV) sulfate, methanol and all chemicals used in this investigation were provided by Aldrich. Metformin- $\mathrm{HCl}$ was purchased from (El-Nasr Company) for Pharmaceutical Chemicals, Cairo, Egypt. 


\subsection{Synthesis}

2.2.1. Synthesis of Schiff-Base and its metal complexes

A methanolic solution of 4-(Diethylamino)benzaldehyde $(1 \mathrm{mmol})$ is added drop wisely to the $(1 \mathrm{mmol})$ metformin solution that is dissolved in $(10 \mathrm{ml})$ methanol. Over a water bath, the mixture is refluxed with continuous stirring for two hours after the addition of a few drops of $\mathrm{NaOH}$. The solution turns to yellow color. The formed pale-yellow product of the synthesized Schiff base (NBM) was washed with a mixture composed of (water and methanol) then dried under vacuum and finally recrystallized from methanol.

Palladium (II) complex $\left[\mathrm{Pd}(\mathrm{NBM}) \mathrm{Cl}_{2}\right]$ was prepared by heating $\mathrm{PdCl}_{2}(1.0 \mathrm{mmol})$ and $\mathrm{KCl}$ $(2.0 \mathrm{mmol}) \mathrm{I}$ the least amount of water to $70^{\circ} \mathrm{C}$ with stirring. The clear solution of $\left[\mathrm{PdCl}_{4}\right]^{2-}$ solution was cooled to $25^{\circ} \mathrm{C}$, filtered and methanolic solution of the prepared Schiff-base (NBM) (1.0 mmol) was added to the stirred solution. An orange crystalline precipitate was obtained; yielded $92 \%$. $\mathrm{C}_{15} \mathrm{H}_{24} \mathrm{Cl}_{2} \mathrm{~N}_{6} \mathrm{Pd}$ (465.72): calcd. C 38.69, H 5.19, N 18.05; found C: $38.01, \mathrm{H} 4.90, \mathrm{~N} 17.42$.

The remaining metal complexes were formed by using the following procedure. Solution of metal chloride (1 mmol) in $5 \mathrm{~mL}$ of methanol was added dropwise to a methanolic solution of the prepared Schiff-base (NBM) $(2 \mathrm{mmol})$ for $(\mathrm{Cu}(\mathrm{II}) \& \mathrm{~V}(\mathrm{IV}))$ and $(1 \mathrm{mmol})$ in case of $\mathrm{Pt}(\mathrm{II})$. Every mixture was refluxed on a water bath for two hours with stirring. The three metal complexes prepared are $\left[\mathrm{Pt}(\mathrm{NBM}) \mathrm{Cl}_{2}\right],\left[\mathrm{Cu}(\mathrm{NBM})_{2} \mathrm{Cl}_{2}\right]$ and $\left[\mathrm{VO}(\mathrm{NBM})_{2}\right]$.

All complexes were filtered, washed and dried as described in Schiff base preparation.

First one $\left[\mathrm{Pt}(\mathrm{NBM}) \mathrm{Cl}_{2}\right]$ was a brown crystalline precipitate; yielded $80 \% . \mathrm{C}_{15} \mathrm{H}_{24} \mathrm{Cl}_{2} \mathrm{~N}_{6} \mathrm{Pt}(554.383)$ : calcd. C: 32.50, H 4.36, N 15.16; found C: 31.71, H 4.20, N 14.42. The second $\left[\mathrm{Cu}(\mathrm{NBM})_{2} \mathrm{Cl}_{2}\right]$ was a pale blue crystalline precipitate; yielded $75 \% . \mathrm{C}_{30} \mathrm{H}_{48} \mathrm{Cl}_{2} \mathrm{CuN}_{12}$ (711.244): calcd. C: 50.66, H 6.80, N 23.63; found C: 50.56, H 6.10, N 22.78.

The third [VO(NBM) $)_{2}$ was a green crystalline precipitate; yielded $80 \% . \mathrm{C}_{30} \mathrm{H}_{46} \mathrm{~N}_{12} \mathrm{OV}$ (641.723): calcd. C: 56.15, H 7.23, N 26.19; found C: 55.56, H 6.10, N 25.78.

The suggested chemical structures of Schiff base and its complexes were represented in (Figure 1). 


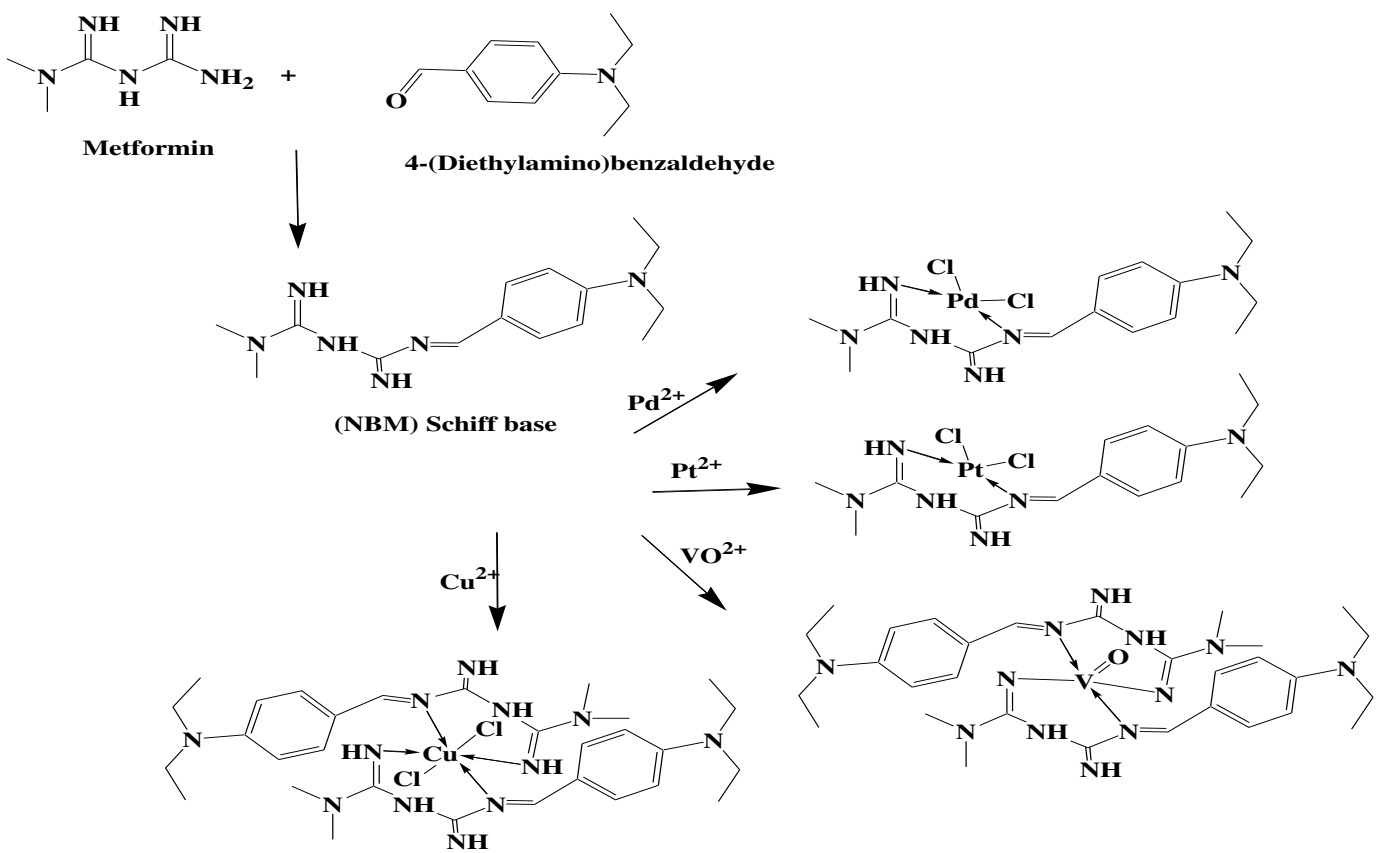

(Figure 1) The chemical structures of (NBM) and its metal complexes 


\subsection{Apparatus and programs}

Automatic analyzer CHNS Vario EL III-Elementar, Germany. Test scan Shimadzu FTIR spectrometer using $\mathrm{KBr}$ disc technique. The spectra were collected in the range $250-4000 \mathrm{~cm}^{-1} .{ }^{1} \mathrm{H}-$ NMR spectra were recorded using $300 \mathrm{MHz}$ Varian-Oxford in DMSO- $\mathrm{d}_{6}$ as a solvent and TMS as an internal standard. Automated UV/Vis-NIR 3101 PC Shimadzu spectrophotometer ranged from 200$900 \mathrm{~nm}$ for measuring electronic absorption spectra in DMF. The conductivity meter ORION model 150 of 0.6 cell constant for measuring molar conductivity of metal complexes. Mass GC-2010 Shimadzu instrument for determination mass spectra of the synthesized compounds. The molar magnetic susceptibility was measured on powdered samples using the Faraday method. The diamagnetic corrections were made by Pascal's constant and $\mathrm{Hg}\left[\mathrm{Co}(\mathrm{SCN})_{4}\right]$ was used as the calibrant. Molar conductivity of metal complexes was measured for $1.00 \times 10^{-3} \mathrm{M}$ DMSO solutions at $25 \pm 1^{\circ} \mathrm{C}$ using the conductivity meter.

MOE 2009 (Molecular Operating Environment) software was used to simulate every enzyme inhibitor. EGFR tyrosine kinase is the selected protein for anticancer activity (PDB ID: 1M17).

The cytotoxicity of all complexes was determined by Vichai and Kirtikara assay [13] using Sulphorhodamine-B (SRB) is a bright pink aminoxanthrene dye has two sulphonic groups. SRB is a protein stain that attaches to the amino groups of intracellular proteins under mildly acidic conditions to provide a sensitive index of cellular protein content. The Cells were seeded in 96-well Microtiter plates at an initial concentration of $3 \times 10^{3}$ cell/well in a $150 \mu 1$ fresh medium and left for 24 hours to attach to the plates. $0,5,12.5,25,50 \mu \mathrm{g} / \mathrm{mL}$ five different concentrations of each drug were added using three wells for each drug concentration. The incubation time for plates was 48 hours. The cells 
fixation time was 1 hour at $4{ }^{\circ} \mathrm{C}$ with $50 \mu \mathrm{l}$ cold trichloroacetic acid $10 \%$ final concentration. At room temperature, the plates stained with $50 \mu 10.4 \%$ SRB dissolved in $1 \%$ acetic acid for 30 minutes. The wells measurements spectrophotometrically at $570 \mathrm{~nm}$ were done by using an ELISA micro plate reader (Sunrise Tecan reader, Germany). The mean value of the background absorbance was automatically subtracted and of drug concentration was calculated. Doxorubicin was used as standard liver antitumor drug. The cell survival percent was calculated by:

Surviving fraction $=$ optical density (O. D.) $($ Treated cells) / O. D. (Control cells).

The $\mathrm{IC}_{50}$ values (the concentrations required to produce $50 \%$ inhibition of cell growth) were also calculated.

The antioxidant activity of all complexes was studied using spectrophotometric technique with 1,1-diphenyl-2-picrylhydrazyl (DPPH) method. It gives a purple solution in methanol. The radical scavenging potentials of the complexes with DPPH radical were evaluated as described [14]. The tested drugs are prepared in different concentrations. Spectrophotometrically at $517 \mathrm{~nm}$, the absorbance of the mixture produced from mixing DPPH and each drug was measured. All test analysis was performed in triplicate. Ascorbic acid (Vitamin C) was taken as the standard drug. DPPH radical scavenging activity $(\%)$ was calculated.

\subsection{Animals}

60 Female Wistar rats ( 8 weeks, 180-250 g), were kept in climate-controlled room in the animal house of National Research Centre at air-conditioned room a maintained temperature and relative humidity $(23 \pm 250 \mathrm{C}, 35-60 \%)$ respectively with $12 \mathrm{~h}$ light- dark cycle, The rats were fed with pellet diet and water.

\subsubsection{Induction of diabetes}

Diabetes mellitus (type 2 diabetes) was induced by intraperitoneal (i.p.) single dose of streptozotocin (STZ) in overnight fasted animals. STZ was freshly prepared (40 mg/Kg body weight) dissolved in $0.1 \mathrm{M}$ citrate buffer ( $\mathrm{pH} 4.5$ ) immediately before use [15-17]. As seen in (Figure 2), after injection, animals had free access to food and water and were given $5 \%$ glucose solution to drink overnight to counter hypoglycemic shock[18]. After 48hrs, body weights as well as blood glucose concentrations of the STZ-injected rats were measured. The samples were taken from the tail vein after $12 \mathrm{hrs}$ overnight fasting conditions. Hyperglycemia was achieved by high glucose level in plasma using a digital glucometer (One Touch Ultra). Rats with blood glucose concentrations greater than 250 
$\mathrm{mg} / \mathrm{dl}$ were considered to be diabetic. Also, blood glucose level and body weights of the rats were measured by the same method every week during the period of experiment.

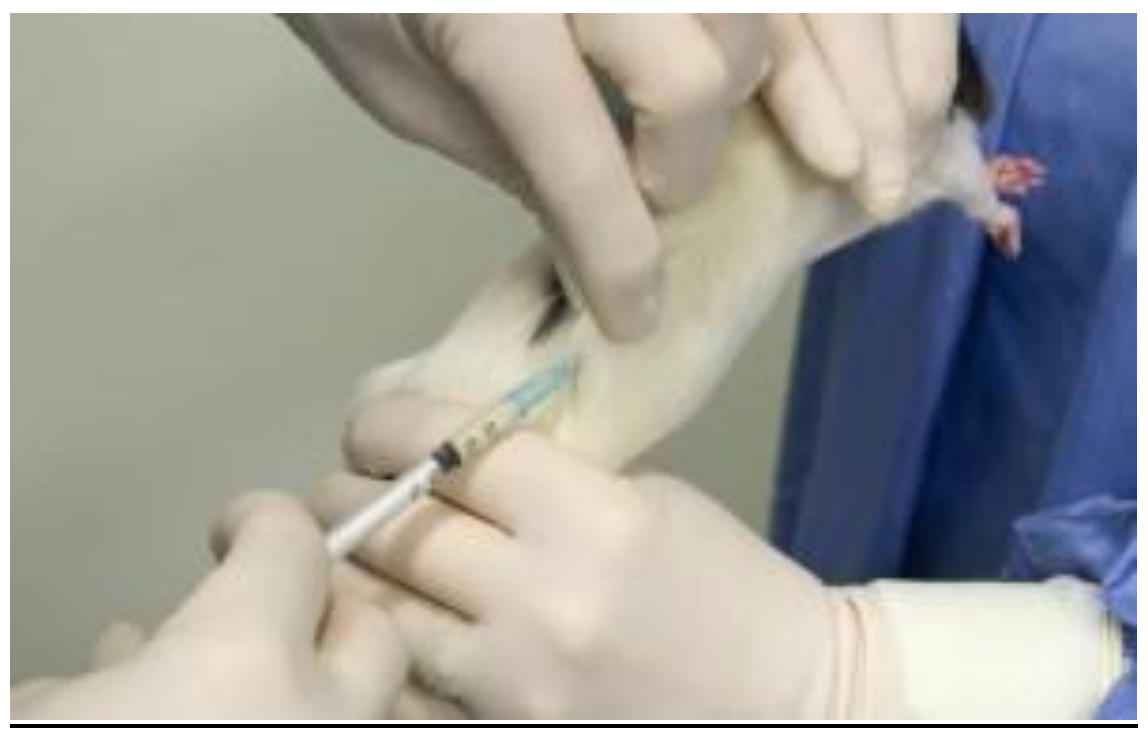

(Figure 2) Streptozotocin (STZ) injection in rats.

\subsubsection{Experimental design}

Rats were divided into eight groups (10 rats in each group) according to the protocol mentioned in (Table 1). Groups 4 - 6 orally injected with the understudied complexes for 30 days $(50 \mathrm{mg} / \mathrm{Kg}$ body weight; the same dose of metformin). At the end of the experiment, the animals were fasted overnight (12-14 hours), the blood samples were taken from each animal in all groups into sterilized tubes for serum separation. Serum was separated by centrifugation at $3000 \times \mathrm{g}$ at $4^{\circ} \mathrm{C}$ for 10 minutes using refrigerated centrifuge (sigma $2 \mathrm{~K} 15$ U.S.A.) and stored at $\left(-80^{\circ} \mathrm{C}\right)$ for further biochemical analysis. After blood collection, all rats of each group were sacrificed under ether anesthesia, the organs (pancreas, liver and kidney) from different animals were immediately removed weighed and washed from blood by ice-cold isotonic saline. A piece of liver was immediately frozen at $\left(-80^{\circ} \mathrm{C}\right)$ for biochemical analyses.

\subsubsection{Preparation of liver homogenate}

Liver tissues were homogenized in either 10 volumes of ice cold bidistilled water (for reduced glutathione "GSH") or 10\% trichloroacetic acid (for nitric oxide "NO" and lipid peroxidation "MDA") using an electrical homogenizer (Janke \& Kunkel, IKA-WERK, Germany). The homogenates were centrifuged at $3000 \times \mathrm{g}$ for 15 minutes at $4{ }^{\circ} \mathrm{C}$, the supernatant was collected and aliquoted in Eppendorf tubes and stored at $\left(-80^{\circ} \mathrm{C}\right)$. The supernatants were used for different biochemical tissue analysis.

\subsection{Biochemical studies}


Nitric oxide (NO), lipid peroxidation (MDA) and reduced glutathione (GSH) were measured in liver homogenate using Biodiagnostic kit. Determination of creatinine and urea were assayed in serum by biodiagnostic kit methods.

\subsection{Statistical Analysis}

Data were analyzed by comparing values for different treatment groups with the values for individual control. All data were expressed as mean \pm standard error of 5 rats in each group. Significant differences between the groups were statistically analyzed using one-way analysis of variance, ANOVA using the spss16 computer program. Differences were considered significant at $\mathrm{p} \leq 0.05$.

\section{Results and discussion}

IR spectrum of novel Schiff base in NBM shows the lack of the $\mathrm{NH}_{2}$ stretching band characteristic of metformin at 3371 with the presence of new strong $\mathrm{C}=\mathrm{N}$ stretching band at $1670 \mathrm{~cm}^{-}$ 1 . In addition to strong splitted band at $(1643 \& 1597) \mathrm{cm}^{-1}$ due to $v(\mathrm{C}=\mathrm{NH})$ imine group of metformin. This suggests the condensation of the aldehyde group and the metformin's primary amino group forming the desired Schiff base (NBM) [19]. (NBM) ligand showed a strong band at (33323043 ) is associated with the presence of three imine groups. Previously, these bands were observed in the spectra of some complexes with biguanide Schiff-bases [20]. Further, bands at (1485\&1269) $\mathrm{cm}^{-}$

1 in the IR spectrum of the prepared ligand were observed due to asymmetric and symmetric $v(\mathrm{~N}-\mathrm{C}-\mathrm{N})[19]$ while, the aromatic $v(\mathrm{C}-\mathrm{H})$ are observed at $2974 \mathrm{~cm}^{-1}$. IR spectra of all complexes sthe how intense band at about $3200 \mathrm{~cm}^{-1}$ region assignable to the $\mathrm{N}-\mathrm{H}$ group stretching vibration [21and 20]. The presence of the IR spectral bands of the imine group $(-\mathrm{C}=\mathrm{NH})$ in complexes are shifted in comparison to the free ligand with significant intensity. This indicates that the ligand is linked to the metal ions through the nitrogen atom of the imine group. The strong band related to $v(\mathrm{C}=\mathrm{N})$ is shifted to a smaller frequency value in all synthesized complexes, meaning its involvement in coordination [22]. Vanadyl complex has a new band at $1701 \mathrm{~cm}^{-1}$ that isn't observed in its parent Schiff base or other complexes. It can be explained due to the induced ionization for one of the imine group $(-\mathrm{C}=\mathrm{NH})$. A band appearing at $1571-1556$ and $1276-1275 \mathrm{~cm}^{-1}$ interval has been specified to $\mathrm{N}-\mathrm{C}-\mathrm{N}$ stretching of symmetric and asymmetric types respectively [23]. The confirmation of metal-ligand bonding is observed by the newly formed bands which are tentatively assigned to $v(\mathrm{M}-\mathrm{N})$ and $v(\mathrm{M}-\mathrm{Cl})[24] . v(\mathrm{M}=\mathrm{O})$ band was observed in case of Vanadyl complex only [19 27]. All characteristic bands were observed in (Table 2).

${ }^{1} \boldsymbol{H N M R}$ for the suggested ligand gave two types of aromatic protons at 7.137-7.108 and 6.661-6.605 ppm while the NH proton is given as a sharp singlet peak at $9.6 \mathrm{ppm}\left(\mathrm{D}_{2} \mathrm{O}\right.$ exchangeable). The peaks obtained at 7.6 and $8.2 \mathrm{ppm}$ are attributable to the two amide protons $\mathrm{C}=\mathrm{NH}\left(\mathrm{D}_{2} \mathrm{O}\right.$ exchangeable). 
The peak recorded at $5.57 \mathrm{ppm}$ is assigned to the azomethine proton [25] while the signal for the methyl protons was observed as a singlet at $\delta=3.25 \mathrm{ppm}$. The peaks recorded at $\delta=3.55$ and 1.112 ppm are assigned to the $\mathrm{CH}_{3}$ and $\mathrm{CH}_{2}$ of $\mathrm{N}$ (Ethyl) group respectively.

After the complexation of NBM ligand, we have two changes in the chemical shifts corresponding to one of the amide protons $\mathrm{C}=\mathrm{NH}$ that placed at $\delta=8.2 \mathrm{ppm}$ and the azomethine proton. It may be explained due to the involvement of both sites of donation in the coordination process. The new values of the amide protons present become at $\delta=8.53$ and $8.456 \mathrm{ppm}$ for $\mathrm{Pd}(\mathrm{II})$ and $\mathrm{Pt}(\mathrm{II})$ complexes respectively. But their azomethine protons become at 5.62 and $5.73 \mathrm{ppm}$ respectively.

All (Pd(II) \& $\mathrm{Pt}(\mathrm{II})$ ) complexes are characterized using ${ }^{1} \mathrm{HNMR}$ technique with the comparison between the complex chart and its parent Schiff base as shown in (Figures 3 and 4). The paramagnetic properties of $\mathrm{Cu}(\mathrm{II})$ and $\mathrm{VO}(\mathrm{IV})$ are troublemakers due to the fast-nuclear spin relaxation induced from their unpaired electrons that significantly broadens their NMR resonances[26 and 27].

The mass spectra are represented to confirm the coincidence between the molecular ion peaks and the formula weights. The results are tabulated in (Table 3), the equations represent the most important fragmentations are seen in (Figure 5). The complexes continue $\mathrm{HN}\left(\mathrm{CH}_{3}\right)_{2}$ species, $\mathrm{Cl}^{-}$and the rest of the Schiff-base. The most abundant fragmentations are mentioned in (Figure 6)

Based on the conductivity, values below $50 \Omega^{-1} \mathrm{ohm}^{-1} \mathrm{~cm}^{2}$ in DMSO solution are for nonelectrolytes [28 and 29]. The molar conductance $\left(\Lambda_{\mathrm{M}}\right)$ values for all prepared complexes are very low indicating that, these complexes are nonelectrolytes and the chloride ion is coordinated in $\mathrm{Pd}(\mathrm{II}), \operatorname{Pt}(\mathrm{II})$ and $\mathrm{Cu}$ (II) complexes. For vanadyl complex, the NBM ligand was undergo induced ionization of the amide proton $\mathrm{C}=\mathrm{NH}$ to make complete neutralization for the metal cationic charge. It was supported before in IR study.

$\mathrm{Pt}(\mathrm{II})$ and $\mathrm{Pd}(\mathrm{II})$ complexes have 0.0 B.M. magnetic moment values due to the diamagnetic properties of the $\mathrm{d}^{8}$ square planar geometry[30 and31]. Copper(II) complex is expected to be in the distorted Octahedral geometry[32] because its measured magnetic moment value is (1.91 B.M.). The measured value is slightly higher than the spin-only value 1.73 B.M. expected for one unpaired electron but falls within the range normally observed for hexa-coordinate $\mathrm{Cu}$ (II) complexes[33]. Vanadyl complex is paramagnetic in the solid-state with the electronic configuration [Ar] $3 \mathrm{~d}^{1}$. Vanadium(IV) has one unpaired electron with a spin-only formula predicting a magnetic moment of 1.73 B.M. The experimental values are in the range of 1.79 B.M. Some monomeric pentacoordinate vanadyl Schiff-bases complexes recorded the previous value [34-37] and are consistent with square pyramidal geometry around the central metal ion [38]. 

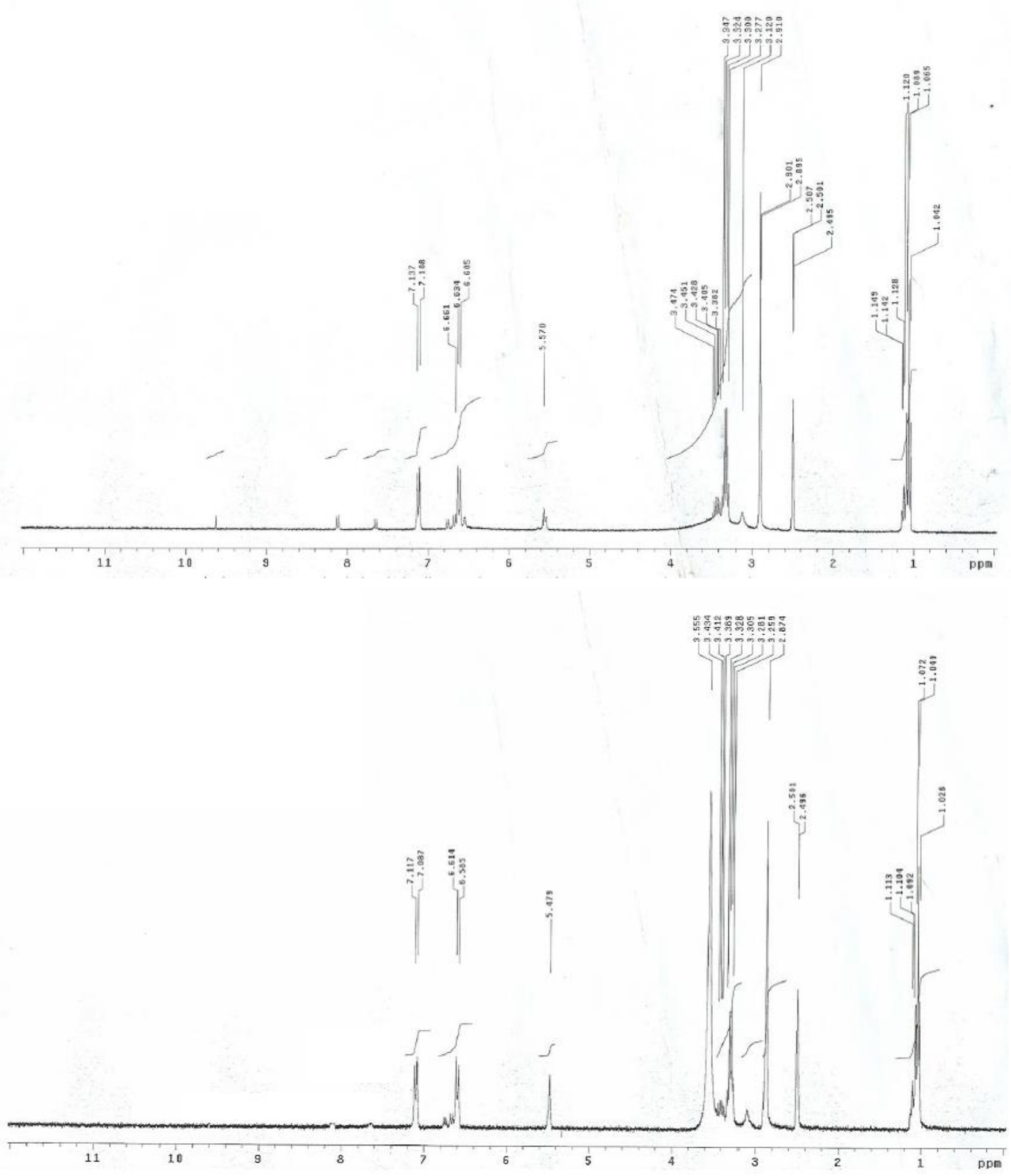

(Figure 3) ${ }^{1}$ HNMR chart of NBM Schiff base 


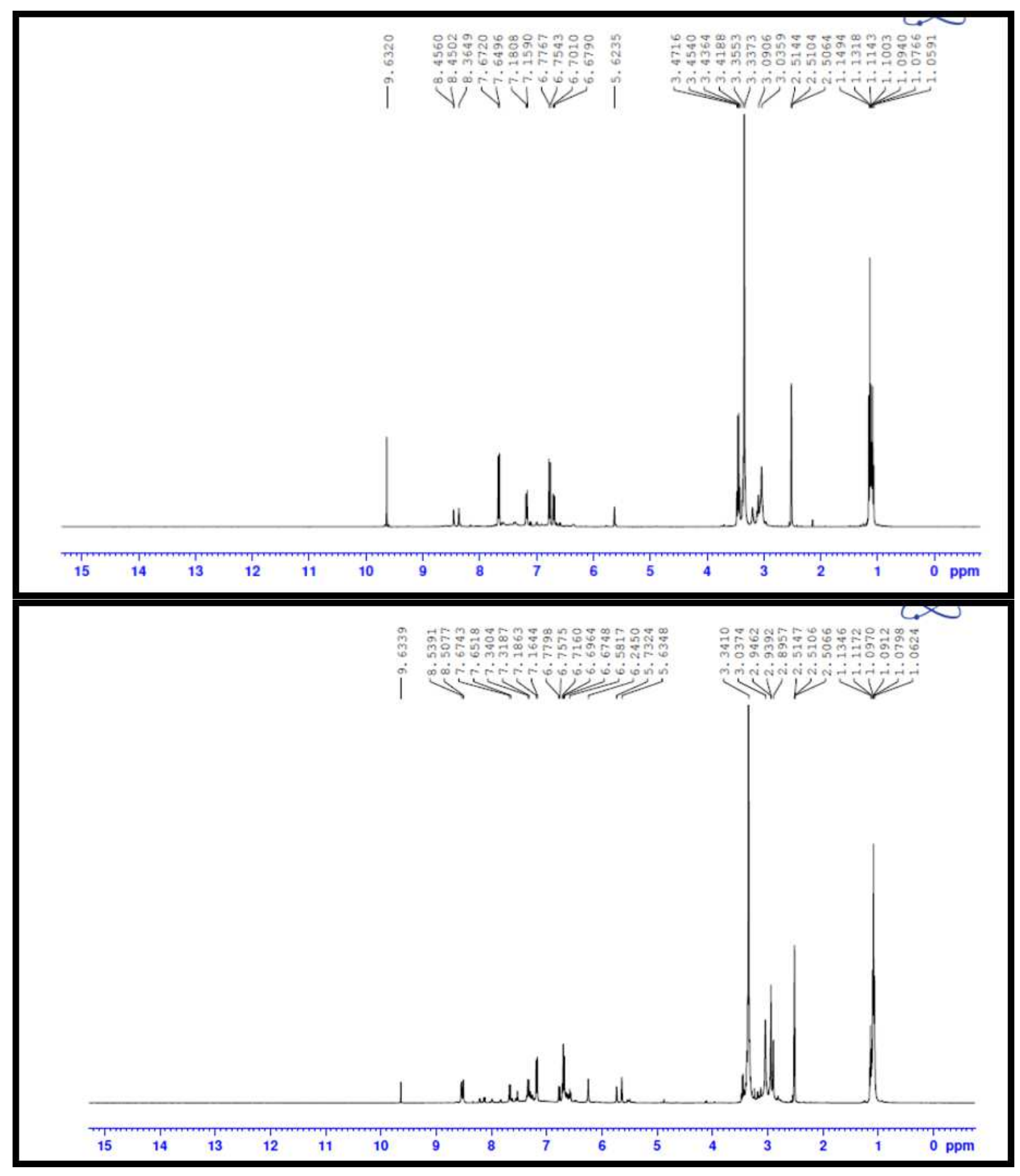

(Figure 4) ${ }^{1} \mathrm{HNMR}$ chart of Pd-NBM and Pt-NBM complexes respectively 


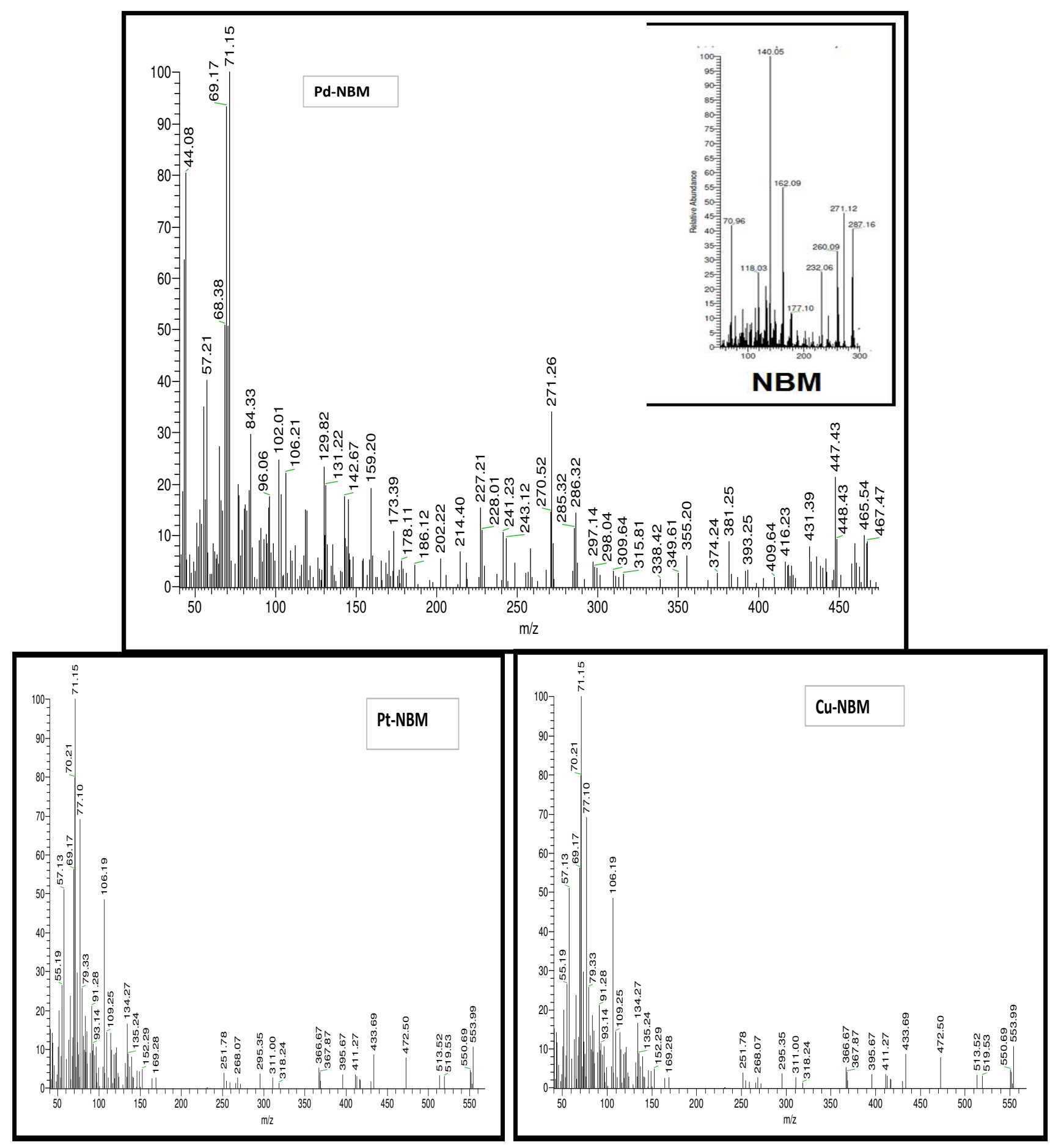

(Figure 5) Mass spectral charts 


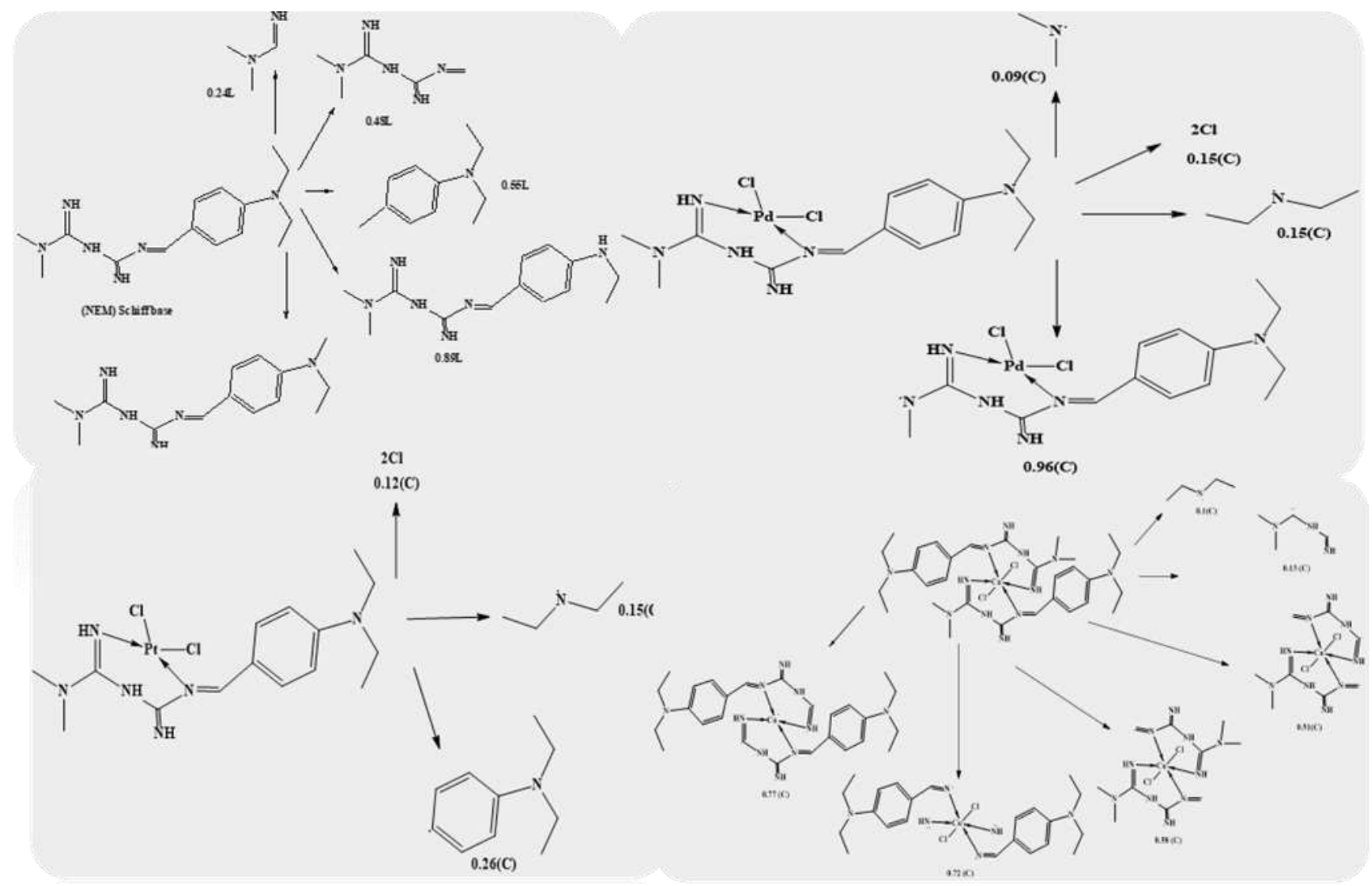

(Figure 6) Some mass fragmentations 


\section{Antidiabetic Investigation}

Hyperglycemia is a state in which a large amount of glucose circulates in the blood plasma. The blood sugar level is more than $11.1 \mathrm{mmol} / \mathrm{L}(200 \mathrm{mg} / \mathrm{dK})$, but symptoms may not start to be noticeable until even higher values such as 15-20mmol/L ( 250-300 mg/L) [39]. Hyperglycemia treatment needs to remove the underlying cause, example diabetes. Direct administration of insulin; in most cases; is used for treatment of acute hyperglycemia while oral hypoglycemic therapy and lifestyle modification is used for severe hyperglycemia [39].

The results in (Table 4) show a significant 4-fold increase in blood glucose levels in STZ administrated rats in comparison to normal control rats. Elevation in blood glucose was decreased; nearly normalized; in the treated animals with metformin, NBM Schiff base and its, Vanadyl (IV) and Copper (II) complexes. STZ- diabetic animals had significantly lower $(\mathrm{P} \leq 0.05)$ body weight and higher kidney weight as well as kidney hypertrophy as compared to those in the normal control group (Table 5). In addition, the different treatment given to diabetic animals ameliorated kidney hypertrophy index and kidney weight after the comparison with STZ-diabetic rats.

The elevation in blood glucose level in STZ-diabetic rats may be attributed to the loss of insulin effect on liver leads to glycogenolysis and increase in hepatic glucose production [39]. Moreover, STZ- diabetes induction leads to inflate and ultimately degenerate the Langerhans islets of $\beta$-cells and consequently, hydrogen peroxide and hydroxyl radicals are generated which have an effective role in the cytotoxicity of STZ. The blood glucose levels reduction in all treated groups may be due to gluconeogenesis and the regulation of serum lipid levels. As displayed in (Table 6), the levels of $\mathrm{NO}$ and MDA in STZ-diabetic group were significantly increased $(\mathrm{P} \leq 0.05)$ compared with normal control group but the level of GSH decreased significantly $(\mathrm{P} \leq 0.05)$ in diabetic animals. The elevation of NO probably due to hyperglycemia-induced oxidative stress. Also, the increase in the levels of NO might be via apoptosis.

In a good agreement with our results El-Baz et al. declared that free radicals act by lipid peroxidation led to release of MDA in a large amount. Thus, MDA concentration in the liver and plasma can detect about the cell damage and apoptosis in diabetic patient and/or animals, which in turn effect on liver and pancreatic tissues showing marked hepatocyte ballooning and hydropic degeneration as well as disarrangement changes in pancreatic blood vessels and interlobular duct. GSH is considered one of the most known non-enzymatic bio-molecules found in tissues that reduce the effect of diabetes via scavenging of free radicals or alter their conversion to hazard products.

After the treatment of diabetic animals with different drug supplementations, the levels of both NO and MDA were significantly decreased, whereas GSH levels were significantly increased $(\mathrm{P} \leq 0.05)$ 
(Table 6). This improvement may be explained due to the elimination of the oxidative stress produced during induction of diabetes. The study of renal function (creatinine and urea) shows highly significant differences in renal function results between the STZ-diabetic rats and normal control group (Figure 7). The present results are in accordance to the work done by Al-Ali et al. [40]. The increase in urea levels may be referred to stimulated protein catabolism and elevation of amino acids for gluconeogenesis. It may also be signs of injury at the glomerular and tubular levels of the kidney [41]. Also, the elevation of creatinine levels in diabetic rats may be accompanied by impaired role of the nephrons [42]. The compounds under test effectively down-modulate renal function. The amelioration in the studied parameters may be referred to controlling blood glucose levels leading to remove of reactive oxygen species (ROS); which are involved in the etiology of several diabetic complications including diabetic nephropathy.

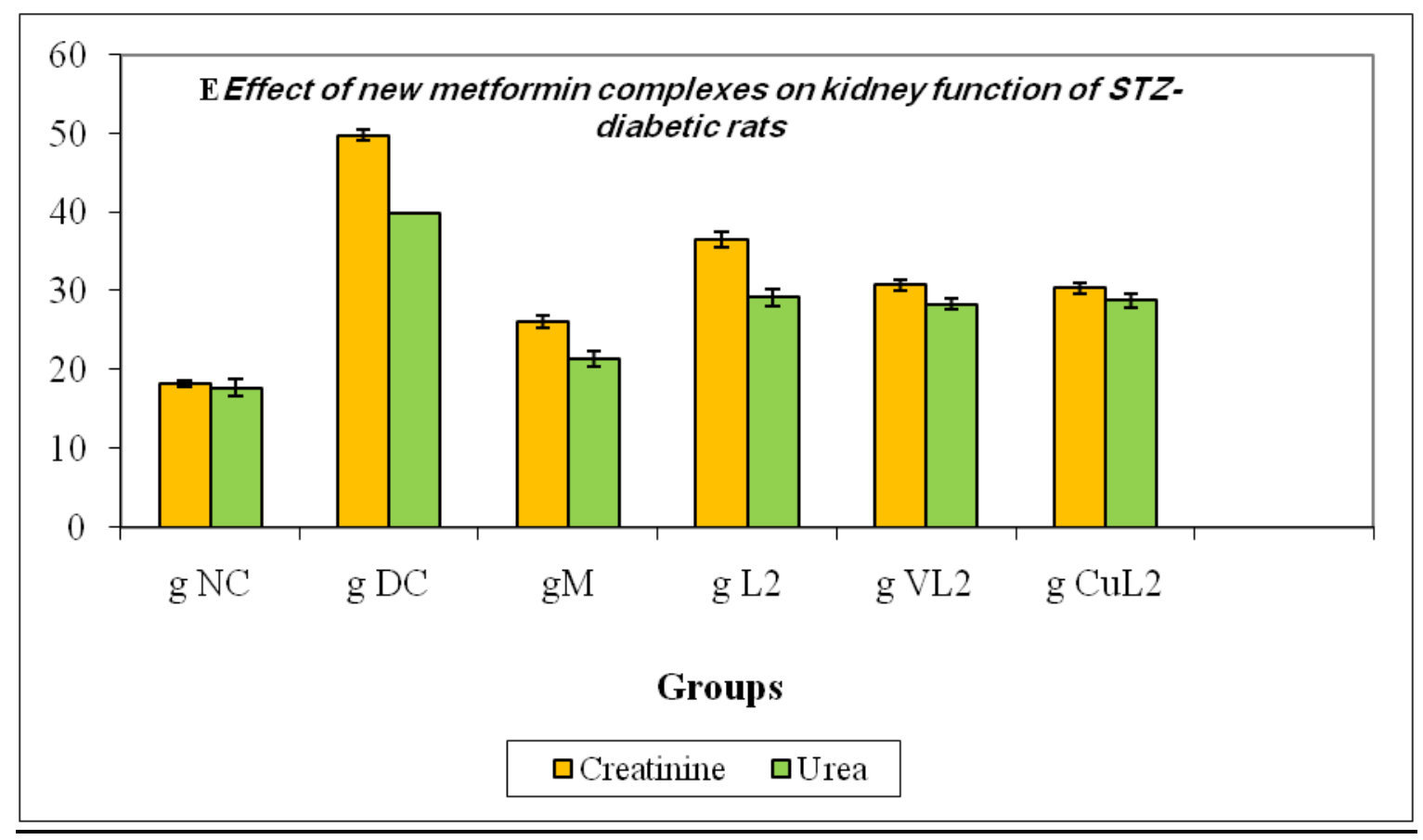

(Figure 7) Effect of new metformin complexes on kidney function of STZ- diabetic rats. Data are expressed as mean \pm SE 5 rats in each group, data are expressed as $\mathrm{mg} / \mathrm{dl}$ for creatinine (mean $x$ 100) and urea, $a$ is the level of significance atP $\leq 0.05$ compared with control group, $b$ is the level of significance at $P \leq 0.05$ compared with diabetic group.

\section{Antioxidant Activity}

The attack of reactive species like free radicals for body cells causing several oxidative damages diseases.

The importance of studying the antioxidants was increased with increasing the human exposure to free radicals' pollution [43]. Metal-derived antioxidant is a recent type that received attention to prove these compounds have a high capacity in scavenging free radicals. 
DPPH (1,1-diphenyl-2-picrylhydrazyl) is stable nitrogen radical and the most famous free radicals used in vitro antioxidant activity where it has an odd electron number with a strong absorption band at $517 \mathrm{~nm}$. The absorption decreases stoichiometrically relative to the number of electrons taken up [44 and 45] by pairing off this electron. On the other hand, DPPH also is decolorized by reducing agents as well as H-transfer. So, we can use DPPH as a substrate to determine the antioxidant activity. We used ascorbic acid (Vitamin C) as standard.

The antioxidant activities of our compounds with ascorbic acid as the standard drug were performed depending on the free radical scavenging effect of the stable DPPH free radical activity. Also, we must calculate $\mathrm{IC}_{50}$ values to test the real strength of tested samples, which define as the concentration needed to diminish certain activity at its half. The investigated changes in the free radical scavenging activity of the test compounds on the basis of percent inhibition are displayed in (Figure 8). From these data, it is clear that the superior complex in antioxidant activity is VO(IV) complex and its activity is more than that of the standard (ascorbic acid). Generally, vanadium element has the highest number of the oxidation states where it contains four common oxidation states $(+2,+3,+4$ and +5$)$, so, it facilitates the donation of an electron to the free radical in vitro therefore, it acts as the strongest reducing agent and oxidized easily. The oxidation state of vanadium element is +4 and acts as an electron donor compound. It can reduce the DPPH radical to DPPH $(\alpha-$ diphenyl- $\beta$-picrylhydrazine) compound, and the VO(IV) ion will be oxidized to its +5 state (from $\mathrm{V}(\mathrm{IV}) \mathrm{O}^{2+}$ to $\mathrm{V}(\mathrm{V}) \mathrm{O}^{+}$) easily [46]. So, this result approves that the modifying of the nucleus of free ligand by the metal has high effective in improvement of the antioxidant activity subsequently, treatment of cancer. The increased antioxidant activity of our metal complexes than parent Schiff base ligand due to electron withdrawing effect of metals which facilitates the discharge of hydrogen to reduce the DPPH. Specially, our compounds have many proton sources. The hydrogen atom will then be abstracted by free radicals, resulting in a stable radical. It is further confirmed by the observed yellow solution produced from the discharge of purple DPPH radical solution, showing scavenging of the DPPH radicals by hydrogen donation. 


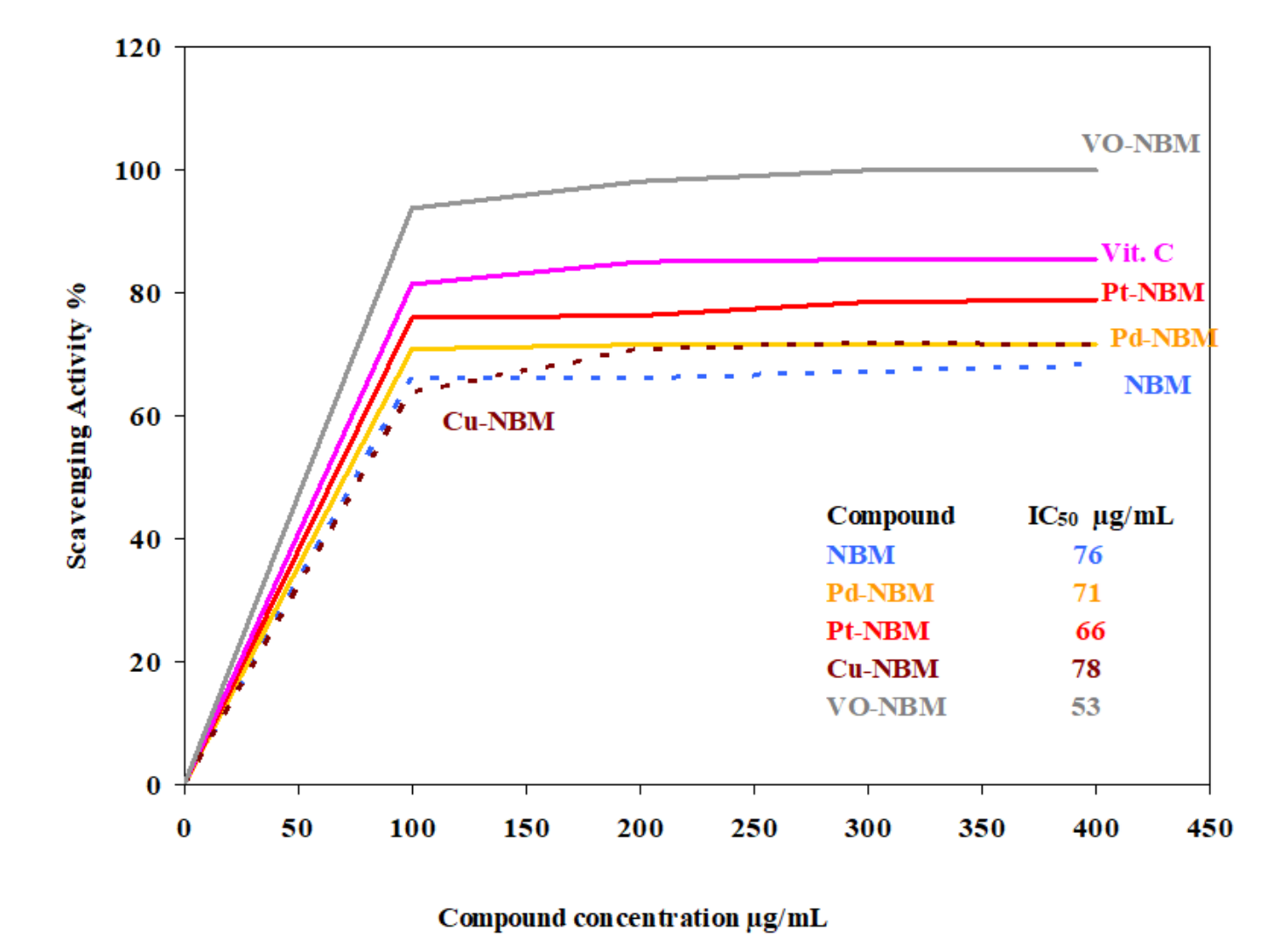

(Figure 8) Scavenging activity of NBM compounds on DPPH radical.

\section{Cytotoxicity and molecular docking Investigation:}

Generally, Cancer is a generic term for a large group of diseases that can affect any part of the body. One of the most frequent malignancy in females is breast cancer. Platinum (Pt) drugs are the most successful class of inorganic medicinal compounds used to treat cancer [47 and 48]. Numerous metals specially $\mathrm{Pd}$ (II) and $\mathrm{Cu}$ (II) complexes have promising activity against tumor cell lines have been synthesized and published [49-54]. In addition to vanadium which has a potential role in tumor growth inhibition and in prophylaxis against different experimental cancer models like; liver cancer, colon cancer, breast cancer and others and in various types of malignant cell lines.

The cytotoxicity of Schiff bases and their metal complexes on human cancer cell line, MCF-7, was ascertained by exposing cells to the medium with varying concentrations of compound (1-50 $\mu \mathrm{g}$ $\mathrm{mL}^{-1}$ ). The results can be seen in (Figure 9). After incubation with complexes a decrease in cell proliferation, it's clear that the activity of metal complexes is higher than that of free ligand (NBM). This indicated an amelioration of the antitumor activity after coordination. This improvement may be related to the positive charge of the metal increasing the acidity of the coordinated ligand that bears protons, causing stronger hydrogen bonds which enhance the biological activity. It seems that 
changing the coordination sites and the nature of the metal ion has a clear effect on the biological activity by altering the binding ability of DNA. Mechanistically, these drugs forming M-DNA complexes that cause DNA damage that accumulate to a point that is beyond repair, finally, leading to cell death [55 and 56]. Vanadium and copper complexes show a higher cytotoxic efficiency by their lower $\mathrm{IC}_{50}$ than the other investigated metal complexes. We can suggest, due to the larger probability of increasing the hydrogen bonds as both complexes were formed as $1(\mathrm{M})$ to 2 (L). we can conclude from our results that vanadium complex have a stronger desired anti-tumor activity. So, it provides a guide to design new Synthetic complexes with effective results.

The antitumor docking study of the ligand and complexes are reported. The most important interaction is the formation of hydrogen bond. The different types of interactions are mentioned in (Table 7) and seen in (Figure 10).

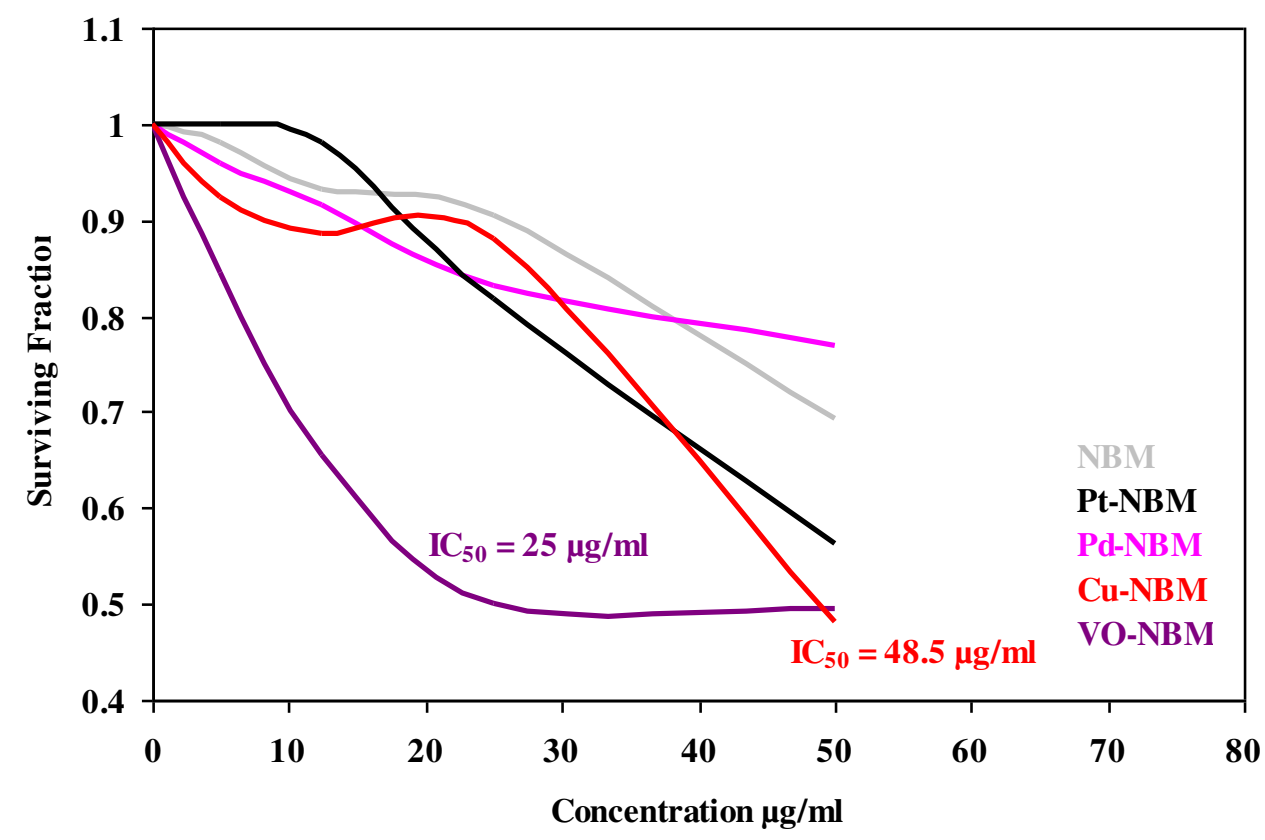

(Figure 9) The surviving fraction of NBM ligand and its metal complexes against MCF7 breast cells. 


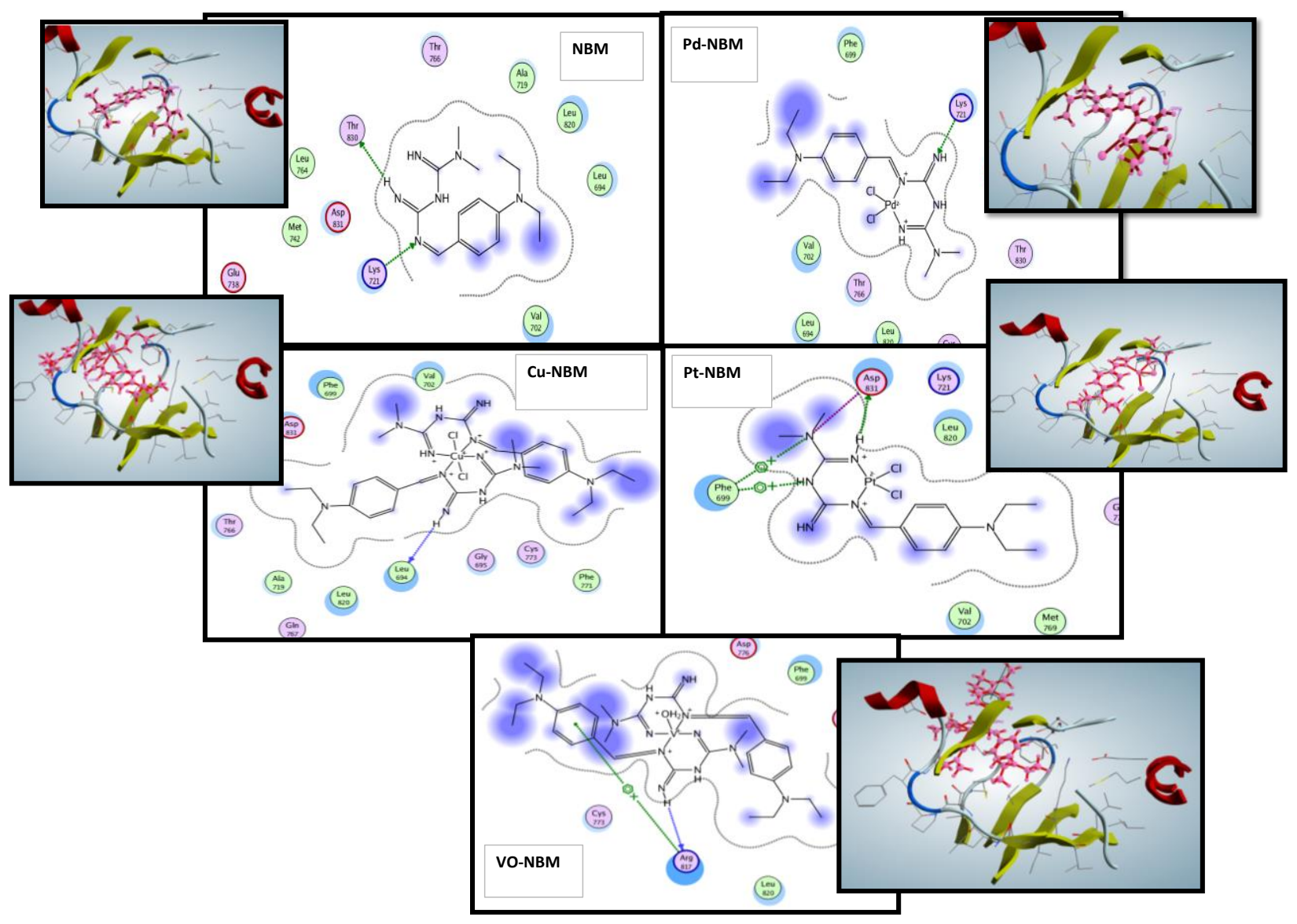

(Figure 10) Binding affinity against EGFR tyrosine kinase receptor (PDB Code: 1M17) 


\section{Molecular docking study of inhibition effect of our compounds against mTOR protein.}

mTOR, is a protein that helps the COVID-19 virus grow so contribute to its severity. So, our target to inhibit mTOR protein by our synthesized compounds. The inhibition was investigated by the study the interaction types and scoring energy between each compound by (4jsv) the protein downloaded from protein data bank. The different interactions are mentioned in (Table 8) and seen in (Figure 11). After investigation, we found that all derived compounds from metformin show better scoring energy and more inhibition of mTOR enzyme than the parent metformin. We noticed metal complexes were more effective in mTOR inhibition that expected to help in COVID-19 virus growing specially vanadium and copper complexes with different types of interactions as arene-cation or side chain acceptor explored the more effective interaction results to the selected protein.

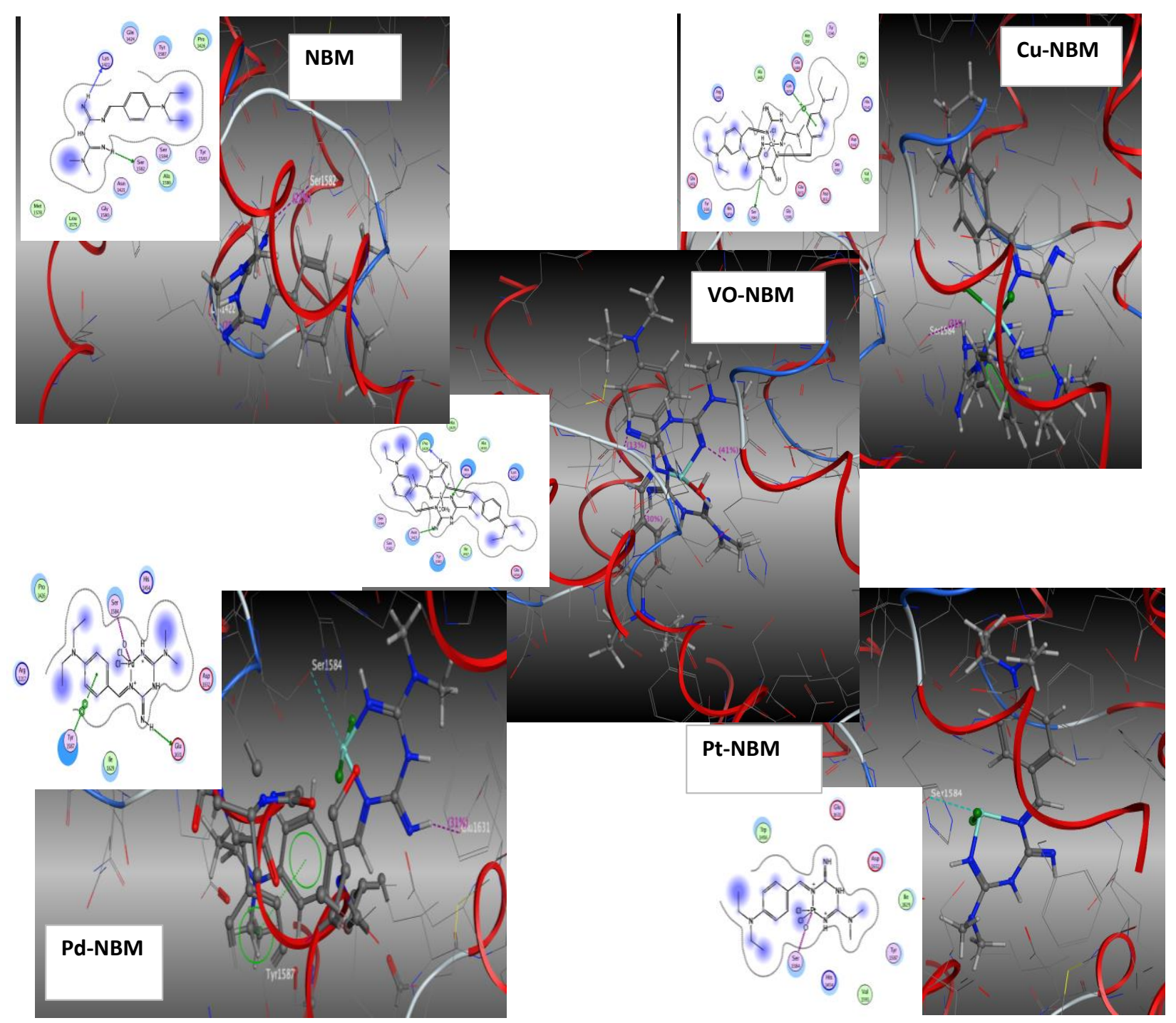

(Figure 11) Binding affinity against mTOR protein receptor (PDB Code: 4 jsv) 
Table.1 Rats were divided into eight groups (10 rats in each group) according to the following protocol:

\begin{tabular}{|l|l|}
\hline Group 1 (NC) & Healthy untreated rats as normal control \\
\hline Group 2(DC) & diabetic untreated control \\
\hline Group 3(M) & $\begin{array}{l}\text { Diabetic rats treated orally with metformin }(50 \mathrm{mg} / \mathrm{Kg} \text { body weight } \\
\text { for 30days })^{[57]}\end{array}$ \\
\hline Group 4 (NBM) & Diabetic rats $+[\mathrm{NBM}]$ \\
\hline Group 5 (VO-NBM) & diabetic rats $+[\mathrm{VO}-\mathrm{NBM}]$ \\
\hline Group 6 (Cu-NBM) & diabetic rats $+[\mathrm{Cu}-\mathrm{NBM}]$ \\
\hline
\end{tabular}

Table 2. The most important IR frequencies bands of NBM ligand and complexes $\left(200-4000 \mathrm{~cm}^{-1}\right)$.

\begin{tabular}{|c|c|c|c|c|c|c|}
\hline Compound & $v(C=N)$ & $v(C-N)$ & $v(N-C-N)$ & $v(M-N)$ & $v(M-C l)$ & v (M-O) \\
\hline NBM & $1670,1643,1597$ & 1269 & 1485,1442 & -------- & -------- & -------- \\
\hline $\mathrm{Pd}(\mathrm{NBM}) \mathrm{Cl}_{2}$ & 1597,1527 & 1265 & 1411,1357 & 308,293 & 270,239 & -------- \\
\hline $\operatorname{Pt}(\mathrm{NBM}) \mathrm{Cl}_{2}$ & $1639,1620,1566$ & 1284 & 1373,1354 & 351,324 & 266,246 & -------- \\
\hline $\mathrm{Cu}(\mathrm{NBM})_{2} \mathrm{Cl}_{2}$ & 1604,1527 & 1242 & 1381,1334 & 339,308 & 246,216 & -------- \\
\hline $\mathrm{VO}(\mathrm{NBM})_{2}$ & $1701,1612,1562$ & 1296 & 1504 & 601 & -------- & 983 \\
\hline
\end{tabular}

Table 3. Some mass fragmentation patterns of ligand and its complexes.

\begin{tabular}{|l|l|l|l|}
\hline Compound & \multicolumn{2}{|c|}{$\mathrm{m} / \mathrm{z}(\mathrm{Wt}$ loss) } & Lost species \\
\hline & Calcd. & Found & Ligand (L), Complex(C) \\
\hline NBM & 288.399 & ------- & ------- \\
\hline & 72.111 & 70.96 & $0.24(\mathrm{~L})$ \\
\hline & 141.178 & 140.05 & $0.48(\mathrm{~L})$ \\
\hline & 163.264 & 162.09 & $0.55(\mathrm{~L})$ \\
\hline & 260.345 & 260.09 & $0.89(\mathrm{~L})$ \\
\hline Pd(NBM)Cl & 465.719 & 271.12 & $0.94(\mathrm{~L})$ \\
\hline & 44.050 & ------- & ------- \\
\hline
\end{tabular}




\begin{tabular}{|c|c|c|c|}
\hline & 69.938 & 69.17 & $0.15(\mathrm{C})$ \\
\hline & 72.081 & 71.15 & $0.15(\mathrm{C})$ \\
\hline & 202.134 & 202.22 & $0.43(\mathrm{C})$ \\
\hline & 449.024 & 448.43 & $0.96(\mathrm{C})$ \\
\hline \multirow[t]{4}{*}{$\mathrm{Pt}(\mathrm{NBM}) \mathrm{Cl}_{2}$} & 554.383 & -------- & -------- \\
\hline & 69.938 & 69.17 & $0.12(\mathrm{C})$ \\
\hline & 72.08 & 71.15 & $0.13(\mathrm{C})$ \\
\hline & 148.113 & 148.29 & $0.26(\mathrm{C})$ \\
\hline \multirow[t]{7}{*}{$\mathrm{Cu}(\mathrm{NBM})_{2} \mathrm{Cl}_{2}$} & 711.244 & -------- & -------- \\
\hline & 72.131 & 69.35 & $0.10(\mathrm{C})$ \\
\hline & 98.072 & 96.9 & $0.13(\mathrm{C})$ \\
\hline & 369.005 & 369.9 & $0.51(\mathrm{C})$ \\
\hline & 413.055 & 412.8 & $0.58(\mathrm{C})$ \\
\hline & 513.136 & 514.21 & $0.72(\mathrm{C})$ \\
\hline & 551.242 & 551.34 & $0.77(\mathrm{C})$ \\
\hline
\end{tabular}

Table 4. Effect of new metformin derivative compounds on blood glucose level of STZ-diabetic rats

\begin{tabular}{|c|c|c|c|c|c|}
\hline \multicolumn{6}{|c|}{ Blood glucose level ( $\mathrm{mg} / \mathrm{dl})$} \\
\hline Compound & After Induction & $1^{\text {st }}$ Week & $2^{\text {nd }}$ Week & $3^{\text {rd }}$ Week & $4^{\text {th }}$ Week \\
\hline g NC & $99.2 \pm 1.6$ & $98.2 \pm 1.4$ & $95.2 \pm 1.6$ & $97.0 \pm 1.5$ & $96.7 \pm 1.7$ \\
\hline g DC & $373.0 \pm 15.2 *$ & $361.7 \pm 12.6^{*}$ & $383.5 \pm 5.9 *$ & $384.0 \pm 9.9 *$ & $386.2 \pm 7.8^{*}$ \\
\hline gM & $390.0 \pm 8.9 *$ & $334.7 \pm 17.0 *$ & $248.2 \pm 14.6^{* a}$ & $172.2 \pm 4.3^{* a}$ & $129.2 \pm 2.6^{* \mathrm{a}}$ \\
\hline g NBM & $391.5 \pm 9.3^{*}$ & $369.5 \pm 9.1 *$ & $252.5 \pm 8.4 * \mathrm{a}$ & $164.2 \pm 3.1 * \mathrm{a}$ & $132.2 \pm 2.7^{* a}$ \\
\hline gVO-NBM & $391.2 \pm 5.5^{*}$ & $361.0 \pm 7.2 *$ & $238.7 \pm 7.1 * \mathrm{a}$ & $154.0 \pm 3.3^{* a}$ & $125.2 \pm 2.2 * \mathrm{a}$ \\
\hline g Cu-NBM & $373.3 \pm 4.9 *$ & $356.7 \pm 8.2 *$ & $237.7 \pm 6.9 * a$ & $188.5 \pm 4.3^{* a}$ & $132.2 \pm 3.4^{* a}$ \\
\hline
\end{tabular}

Data are expressed as mean \pm SE 5 rats in each group, * is the level of significance at $\mathrm{P} \leq 0.05$ compared with normal control group, ${ }^{\text {a }}$ is the level of significance at $\mathrm{P} \leq 0.05$ compared with diabetic group. 
Table 5. Effect of new metformin derivative compounds on body weight, kidney weight and kidney hypertrophy of STZ -diabetic rats

\begin{tabular}{|l|c|c|c|}
\hline Groups & Body weight (gm) & Kidney weight (gm) & Kidney \\
& 4th week & & (kidney wt / body wt) $\%$ \\
\hline $\boldsymbol{g} \mathbf{N C}$ & $188.7 \pm 2.5$ & $1.23 \pm 0.015$ & $0.65 \pm 0.011$ \\
\hline $\boldsymbol{g} \mathbf{D C}$ & $122.5 \pm 1.8^{*}$ & $1.64 \pm 0.025^{*}$ & $1.33 \pm 0.006^{*}$ \\
\hline $\boldsymbol{g} \boldsymbol{M}$ & $162.7 \pm 3.4^{* a}$ & $1.32 \pm 0.022^{* a}$ & $0.81 \pm 0.025^{* a}$ \\
\hline $\boldsymbol{g} \mathbf{N B M}$ & $156.5 \pm 3.6^{* a}$ & $1.45 \pm 0.023^{* a}$ & $0.93 \pm 0.034^{* a}$ \\
\hline $\boldsymbol{g} \mathbf{V O}-\mathbf{N B M}$ & $166.0 \pm 2.1 * a$ & $1.36 \pm 0.014^{* a}$ & $0.81 \pm 0.011^{* a}$ \\
\hline $\boldsymbol{g} \mathbf{C u}-\mathbf{N B M}$ & $165.7 \pm 2.7^{* a}$ & $1.29 \pm 0.035^{a}$ & $0.77 \pm 0.024^{* a}$ \\
\hline
\end{tabular}

Data are expressed as mean \pm SE 5 rats in each group, ${ }^{*}$ is the level of significance at $\mathrm{P} \leq 0.05$ compared with normal control group, ${ }^{\text {a }}$ is the level of significance at $\mathrm{P} \leq 0.05$ compared with diabetic group

Table 6. Effect of new metformin derivative compounds on antioxidant markers of STZ- diabetic rats

\begin{tabular}{|c|c|c|c|}
\hline Groups & $\begin{array}{c}\text { NO } \\
(\mu \mathrm{mol} / \mathrm{ml})\end{array}$ & $\begin{array}{c}\text { MDA } \\
(\mathrm{nmol} / \mathrm{ml})\end{array}$ & $\begin{array}{c}\text { GSH } \\
(\mathrm{mmol} / \mathrm{ml})\end{array}$ \\
\hline$g N C$ & $13.74 \pm 0.68$ & $0.288 \pm 0.006$ & $110.5 \pm 4.11$ \\
\hline$g D C$ & $34.00 \pm 1.47 *$ & $0.682 \pm 0.003^{*}$ & $43.49 \pm 2.73 *$ \\
\hline$g M$ & $21.10 \pm 1.09 * \mathrm{a}$ & $0.342 \pm 0.003 * a$ & $93.50 \pm 2.39 * a$ \\
\hline$g N B M$ & $23.70 \pm 1.98 * a$ & $0.402 \pm 0.003 * a$ & $85.50 \pm 4.94 * \mathrm{a}$ \\
\hline g VO-NBM & $22.50 \pm 1.44 * \mathrm{a}$ & $0.354 \pm 0.006 * a$ & $93.50 \pm 2.39 * a$ \\
\hline g Cu-NBM & $22.75 \pm 1.65^{* a}$ & $0.350 \pm 0.003^{* a}$ & $87.50 \pm 1.84 * \mathrm{a}$ \\
\hline
\end{tabular}

Data are expressed as mean \pm SE 5 rats in each group, * is the level of significance at $\mathrm{P} \leq 0.05$ compared with control group,

${ }^{a}$ is the level of significance at $\mathrm{P} \leq 0.05$ compared with diabetic group. 
Table 7. Binding affinity of complexes against EGFR tyrosine kinase receptor (PDB Code: 1M17)

\begin{tabular}{|l|l|l|}
\hline \multicolumn{2}{|c|}{ Antitumor docking 1M17 } \\
\hline Compound & Involved amino acids & Type of interaction \\
\hline NBM & Thr-830 and Lys-721 & Side chain donor \& side chain acceptor \\
\hline Pd-NBM & Lys-721 chain acceptor \\
\hline Pt-NBM & Phe-699 and Asp-831 & Arene-cation interaction and (side chain donor\& metal \\
& contact) \\
\hline Cu-NBM & Leu-694 & backbone donor \\
\hline VO-NBM & Arg-817 & Arene-cation interaction and backbone donor \\
\hline
\end{tabular}

Table 8. Binding affinity of complexes against mTOR protein receptor (PDB Code: 4jsv).

\begin{tabular}{|l|l|l|}
\hline \multicolumn{2}{|l|}{ Docking 4jsv } \\
\hline Compound & $\begin{array}{l}\text { Involved amino acids(scoring energy } \\
\text { kcal/mol ) }\end{array}$ & Type of interaction \\
\hline Metformin & Asp-1632 and Ser-1584(-1.63) & Side chain acceptor and backbone acceptor \\
\hline NBM & Ser1582 and lys1422(-4.57) & $\begin{array}{l}\text { Metal solvent contact, Side chain acceptor } \\
\text { and Backbone acceptor }\end{array}$ \\
\hline Pd-NBM & Ser-1584, Glu-1631and Tyr-1587(-6.80) & $\begin{array}{l}\text { Metal solvent contact, Side chain acceptor } \\
\text { and Arene-arene interaction }\end{array}$ \\
\hline Pt-NBM & Ser-1584 (-5.99) & $\begin{array}{l}\text { Metal solvent contact } \\
\text { Cu-NBM }\end{array}$ \\
\hline VO-NBM & Ser-1584 and Lys-1635(-9.56) & interaction \\
\hline
\end{tabular}




\section{Conclusion}

In this work the Schiff bases were prepared from condensation reaction of metformin non-expensive drug with aldehydic compound [4-(Diethylamino)benzaldehyde(NBM). Different metal complexes were prepared using $\mathrm{Pd}(\mathrm{II}), \mathrm{Pt}(\mathrm{II}), \mathrm{Cu}(\mathrm{II})$ and $\mathrm{V}(\mathrm{IV})$ metal ions. Vanadium (IV) and $\mathrm{Cu}$ (II) complexes derived from (NBM) Schiff base showed higher cytotoxic activity against breast cancer cell lines than the parent ligand or other metal complexes. Also, both complexes have a potential blood-glucose-lowering effect higher than the commercial metformin drug. VO(IV) complex has superior antioxidant activity more than the other synthesized compounds and the standard ascorbic acid. The high activity can be related to the large number of its variable oxidation states. Molecular docking investigation proved that; all synthesized compounds had interesting interactions with the active site amino acids of EGFR tyrosine kinase (anticancer activity). The most interesting result in this work is the pioneer of vanadium, copper, platinum and palladium complexes in inhibition of mTOR protein expected to be responsible for COVID-19 virus growing.

\section{References:}

[1] A. A. EL-Arabey Update on off label use of metformin for obesity, Prim Care Diabetes, 2018,12,284-285. doi: 10.1016/j.pcd.2018.02.004

[2] A. A. EL-Arabey, M. Abdalla and W. A. Eltayb, Metformin: Ongoing Journey with Superdrug Revolution, Adv Pharm Bull, 2019,9, 1-4. doi: 10.15171/apb.2019.001

[3] Y. Chen, F. Gu and G. J. Long, Metformin Might Inhibit Virus through Increasing Insulin Sensitivity. Chin Med J (Engl), 2018, 131, 376-377. doi: 10.4103/0366-6999.223856

[4] A. Leone, E. Di Gennaro, F. Bruzzese, A. Avallone and A. Budillon, New perspective for an old antidiabetic drug: metformin as anticancer agent, Cancer Treat Res, 2014, 159, 355. doi: $10.1007 / 978-3-642-38007-5 \_21$

[5] K. Moodley, K. Joseph and Y. Naidoo et al, Antioxidant, antidiabetic and hypolipidemic effects of Tulbaghia violacea Harv. (wild garlic) rhizome methanolic extract in a diabetic rat model. BMC Complement Altern Med, 2015,15,408. https://doi.org/10.1186/s12906-015-0932-9

[6] B. Rosenberg and L. van Camp, The Successful Regression of Large Solid Sarcoma 180 Tumors by Platinum Compounds, Cancer Res, 1970, 30, 1799. DOI:PMID: 5457941

[7] J. P. Davidson, P. J. Faber, R. G. Fisher, S. Mansy, H. J. Peresie, B. Rosenberg and L. van Camp, Platinum-pyrimidine blue and related complexes: a new class of potent anti-tumor agents, Cancer Chemother, 1975, 59, 287-290. PMID: 1149007. 
[8] M. M. Shoukry, A. A. Shoukry, P. A. Khalf Alla and S. S. Hassan, Equilibrium and Kinetic Investigation of the Interaction of Model Palladium(II) Complex with Biorelevant Ligands, Int J Chem Kinet, 2010, 42,608-618. doi:10.1002/kin.20511.

[9] A. Al-Alousi, P. A. Khalf Alla, S. S. Hassan and M. M. Shoukry, Coordination properties of Palladium(II) complex taken as a model of an antitumour agent with some selected amino acids, peptides and DNA constituents. JAC, 2014,9,2046-2055. DOI: 10.24297/jac.v9i3.1011

[10] S. S. Hassan and S. M. Gomha, Novel functionalized thiosemicarbazone ligands and their $\operatorname{Pd}(\mathrm{II})$ complexes: synthesis, characterization, antibacterial and cytotoxic activities, Chem Pap, 2019, 73,331-344. https://doi.org/10.1007/s11696-018-0592-6

[11] E. M. Shoukry, N. G. Hosny, M. F. Amin and E. F. Mohamed. Mixed Ligand Complex Formation Reactions and Equilibrium Studies of Diaqua (N-Methylethylenediamine) Palladium (II) With Various Biologically Relevant Ligands, JCBPS, 2016, 6,1308-1328.

[12] S. Rangarajan, N. B. Bone, A. A. Zmijewska, S. N. Jiang, D. W. Park and K. Bernard et al. Metformin reverses established lung fibrosis in a bleomycin model. Nat Med, 2018, 24,1627. doi: 10.1038/s41591-018-0170-z

[13] G. Furstenberger and S. H. Jorg, Insulin-like growth factors and cancer, Lancet Oncol, 2002,3,298-302. doi: 10.1016/s1470-2045(02)00731-3.

[14] S. Gandini, M. Puntoni, B. M. Heckman-Stoddard, B. K. Dunn, L. Ford, A. De Censi and E. Szabo, Metformin and cancer risk and mortality: a systematic review and meta-analysis taking into account biases and confounders, Cancer Prevention Research, 2014, 7, 867. doi: 10.1158/19406207.CAPR-13-0424.

[15] A. J. Emerick, M. P. Richards, G. L. Kartje, E. J. Neasfsey and E. B. Stubbs, Experimental Diabetes Attenuates Cerebral Cortical-Evoked Forelimb Motor Responses, Diabetes, 2005, 54,2764. https://doi.org/10.2337/diabetes.54.9.2764

[16] E. Milani, S. Nikfar, R. Khorasani, M. J. Zamani and bdollahi, Reduction of diabetes-induced oxidative stress by phosphodiesterase inhibitors in rats, Comparative Biochemistry and Physiology Part C: Toxicology pharmacol 2005, 140, 251. https://doi.org/10.1016/j.cca.2005.02.010 
[17] V. R. Punithavathi, R. Anuthama and S. M. P. Prince, Combined treatment with Naringin and vitamin C ameliorates STZ induced diabetes in male Wistar rats, J. Appl. Toxicol, 2008, 28, 806-813. DOI: $10.1002 /$ jat.1343

[18] U. Bhandari, R. Kanojia and K. Pillai, Effect of ethanolic extract of Zingiber officinale on dyslipidaemia in diabetic rats, J. Ethnopharmacol, 2005, 97, 227. doi: 10.1016/j.jep.2004.11.011

[19] M. A. Mahmoud, A. A. Ammar and S. A. Sallam, Synthesis, characterization and toxicity of Cu (II) complexes with metformin Schiff-bases, J Chin Adv. Mter Soc, 2017, 5, 79-102. ttps://doi.org/10.1080/22243682.2017.1296370

[20] R. Olar, M. Badea, D. Marinescu, E. Iorgulescu, S. Stoleriu, Ni(II) complexes with ligands resulted in condensation of N,N-dimethylbiguanide and pentane-2,4-dione, J. Therm Anal Calorim ,2005,80, 363-367. https://doi.org/10.1007/s10973-005-0661-2.

[21] J. Gao, A Weak Hydrolytical Copper(II) Complex Derived from Condensation of N,N-Dimethylbiguanide with 2-Pyridinecarbaldehyde Synthesis, Crystal Structure and Biological Activity, Synth React Inorg, 2007,37, 621. https://doi.org/10.1080/15533170701608833

[22] K. Nakamoto, Part II: applications in coordination, organometallic, and bioinorganic chemistry. $5^{\text {th }}$ ed. New York: Wiley 1997.

[23] F. A. Al-Saif, M.S. Refat, Synthesis, spectroscopic, and thermal investigation of transition and non-transition complexes of metformin as potential insulin-mimetic agents, $J$ Therm Anal Calorim, 2013, 111, 2079-2096. https://doi.org/10.1007/s10973-012-2459-3

[24] H. Sakurai, Y. Fujisawa, S. Fujimoto, H. Yasaui, T. Takino, Role of vanadium in treating diabetes, J Trace Elem Exp Med, 1999,12, 393.

https://doi.org/10.1002/(SICI)1520-670X(1999)12:4\%3C393::AID-JTRA13\%3E3.0.CO;2-P

[25] K. Yao, N. Li and L. Shen, Synthesis and catalytic activity of Ln (III) complexes with an unsymmetrical Schiff base including multi $\mathrm{C}==\mathrm{N}-$ groups, Sci. Chin. Ser.B, 2003, 46, 75. https://doi.org/10.1360/03yb9011 
[26] A. A. Diamantis and J. V. Dubrawski. Preparation and coordination geometry of quadridentate ethylenediaminetetraacetate complexes of ruthenium(II) and -(III), Inorg. Chem, 1983,22,1934. https://doi.org/10.1021/ic00155a022

[27] T. Storr, B. R. Cameron, R. A. Gossage, Y. Yee, R. T. Skerlj, M. C. Darkes and S. P. Fricker, Bridger GJ, Davies NA, Wilson MT, Maresca KP , Zubieta J. Ru ${ }^{\mathrm{III}}$ complexes of edta and dtpa polyaminocarboxylate analogues and their use as nitric oxide scavengers, Eur. J. Inorg. Chem, 2005, 2685. https://doi.org/10.1002/ejic.200500018

[28] W. J. Geary, The Use of Conductivity Measurements in Organic Solvents for the Characterisation of Coordination Compounds, Coord. Chem. Rev., 1971,7,81122.http://dx.doi.org/10.1016/S0010-8545(00)80009-0

[29] L. K. Thompson, F. L. Lee and E. J. Gabe, Variable antiferromagnetic exchange in a series of binuclear copper(II) complexes of tetradentate (N4) and hexadentate (N6) diazine ligands. Magnetism versus structure, bridging and terminal ligand groups, and chelate ring size. Crystal and molecular structure of[.mu.-1,4-bis((6-methylpyrid-2-yl)amino)phthalazine](.mu.-hydroxo)(.mu.nitrato-O)-bis(nitrato)dicopper(II)-0.5-water, Cu2C20H19N9O10.cntdot.0.5H2O, Inorg. Chem, 1988, 27, 39-46 https://doi.org/10.1021/ic00274a010

[30] D. M. A. Melo, G. Vicentini, L. B. Zinner, C. A. Dc. Simone, E. E.Castcllano, Inorg. Chim. Acta, 1988, 146, 123.

[31] S. Milewski, H. Chmara and E. Borowski, Antibiotic tetaine a selective inhibitor of chitin and mannoprotein biosynthesis in Candida albicans, Arch. Microbio 1986,145,234. https://doi.org/10.1007/BF00443651

[32] A. B. P. Lever."Inorganic electronic spectroscopy", 2nd ed., Elsevier, New York 1984.

[33] B. K. Patel and M. M. Patel, 2,4 - Dihydroxybenzaldehyde oxime - formaldehyde polymer as a polymeric ligand, Indian J. Chem, 1990, 29,90. http://nopr.niscair.res.in/handle/123456789/46245 
[34] M. Xie, G. Xu, L. Li, W. Liu, Y. Niu and S. Yan, In vivo insulin-mimetic activity of [N,N'-1,3propyl-bis(salicyladimine)]oxovanadium(IV), Eur. J Med Chem, 2007, 42, 817. https://doi.org/10.1016/j.ejmech.2006.12.021

[35] A. M. B. Bastos, J. G. da Silva, P. I. S. Maia, V. M. Deflon, A. A. Batista, A. V. M. Ferreira, L. M. Botion, E. Niquet and H. Beraldo, Oxovanadium(IV) and (V) complexes of acetylpyridinederived semicarbazones exhibit insulin-like activity, Polyhedron, 2008, 27, 1787-1794. https://doi.org/10.1016/j.poly.2008.02.014

[36] I. C. Mendes, L. M. Botion, A. V. M. Ferreira, E. E. Castellano and H. Berlado, Vanadium complexes with 2-pyridineformamide thiosemicarbazones: in vitro studies of insulin-like activity, Inorg Chim Acta, 2009, 362, 414-420. DOI: 10.1016/j.ica.2008.04.029

[37] A. A. Nejo, G. A. Kolawole, A. R. Opoku, J. Wolowska and O. B. rien, Synthesis, characterization and preliminary insulin-enhancing studies of symmetrical tetradentate Schiff base complexes of oxovanadium(IV), Inorg Chim Acta, 2009, 362, 3993 https://doi.org/10.1016/j.ica.2009.05.039

[38] A. B. P. Lever, Electronic spectra of some transition metal complexes: Derivation of Dq and B.,J Chem Edu, 1968,45,711. https://doi.org/10.1021/ed045p711

[39] K. S. Clin, Serum lipid peroxide in cerebrovascular disorders determined by a new colorimetric method, Chim. Acta, 1978, 90, 37. doi:10.1016/0009-8981(78)90081-5

[40] K. Al-Ali, H. S. Abdel Fatah and Y. El badry, Dual Effect of Curcumin-Zinc Complex in Controlling Diabetes Mellitus in Experimentally Induced Diabetic Rats, Biol. Pharm. Bull, 2016,39, 1774. http://dx.doi.org/10.1248/bpb.b16-00137

[41] L. Bankjr, N. Bouby, M. Trinh-Trang-Tan, M. Ahloulay and D. Promeneur, Direct and indirect cost of urea excretion, Kidney International, 1996, 49,1598 - 1607.

[42] N. M. Elsherbiny, M. M. Al-Gayyar, The role of IL-18 in type 1 diabetic nephropathy: The problem and future treatment, Cytokine 2016, 81, 15. https://doi.org/10.1016/j.cyto.2016.01.014

[43] P. Molyneux, The Use of Stable Free Radical Diphenylpicrylhydrazyl (DPPH) for Estimating Antioxidant Activity, J. Sci. Technol, 2004, 26, 211.

[44] G. Nizami and R. Sayyed Antimicrobial, electrochemical and thermodynamic studies of Schiff base complexes and their potential as anticarcinogenic and antitumor agents, $J$ Chem Tech \& Biotechy, 2017, 10, 40-51. DOI: 10.9790/5736-1010014051 
[45] A. Wolfe, G. H. Shimer and T. Meehan, Polycyclic aromatic hydrocarbons physically intercalate into duplex regions of denatured DNA, Biochemistry, 1987,26,6392-6396. https://doi.org/10.1021/bi00394a013

[46] D. Sanna, V. Ugone, A. Fadda, G. Micera and E. Garibba, Behavior of the potential antitumor VIVO complexes formed by flavonoid ligands. 3. Antioxidant properties and radical production capability, J Inorg Biochem, 2016, 161,18-26. DOI: 10.1016/j.jinorgbio.2016.04.027

[47] B. Desoize, Metals and metal compounds in cancer treatment, Anticancer Res, 2004, 24, 15291544. PMID: 15274320

[48] L. Kelland, The resurgence of platinum-based cancer chemotherapy, Nat Rev Cancer, 2007,7,573- 584 . doi: 10.1038/nrc2167

[49] M. M. El-ajaily, A. K. Sarangi, R. K. Mohapatra, S. S. Hassan, R. N. Eldaghare, P. K. Mohapatra, M. K. Raval, D. Das, A. Maha, A. Cipurkovic, T. H. Al-Noor, Transition Metal Complexes of (E)-2((2- hydroxybenzylidene) amino-3-mercaptopropanoic acid: XRD, Anticancer, Molecular modeling and Molecular Docking Studies, ChemistrySelect, 2019, 4, 9999-10005. DOI: 10.1002/slct.201902306

[50] S. S. Hassan, E. F. Mohamed, Antimicrobial, antioxidant and antitumor activities of NanoStructure Eu (III) and La (III) complexes with nitrogen donor tridentate ligands, Appl. Organomet. Chem, 2020,34, 1-11. https://doi.org/10.1002/aoc.5258

[51] S. S. Hassan, P. A. KhalfAlla, Anti-hepatocellular carcinoma, antioxidant, anti-inflammation and antimicrobial investigation of some novel first and second transition metal complexes, Appl. Organomet. Chem, 2020, 34, 1-15. https://doi.org/10.1002/aoc.5432

[52] P. A. Khalf-Alla, A. H. Basta, V. F. Lotfy, S. S. Hassan, Synthesis, Characterization, Speciation, and Biological Studies on Metal Chelates of Carbohydrates with Molecular Docking Investigation, Macromol. Mater. Eng, 2021, 306,1-15. DOI: 10.1002/mame.202000633 
[53] C. Marzano, M. Pellei, F. Tisato, C. Santini, Copper complexes as anticancer agents, Anti Cancer Agents Med Chem, 2009,9, 185. https://doi.org/10.2174/187152009787313837

[54] C. Santini, M. Pellei, V. Gandin, M. Porchia, F. Tisato and C. Marzano, Advances in copper complexes as anticancer agents, Chem Rev, 2014, 114, 815. https://doi.org/10.1021/cr400135x

[55] T. C. Johnstone, G. Y. Park, S. J. Lippard, Understanding and improving platinum anticancer drugs - phenanthriplatin, Anticancer Res, 2014, 34, 471. PMID: 24403503; PMCID: PMC3937549.

[56] D. Wang, S. J. Lippard, Cellular processing of platinum anticancer drugs, Nat Rev Drug Discov, 2005,4, 307. https://doi.org/10.1038/nrd1691

[57] C. H. Tseng, Prostate cancer mortality in Taiwanese men: Increasing age-standardized trend in general population and increased risk in diabetic men, Ann Med, 2011,43,142. https://doi.org/10.3109/07853890.2010.530683

Funding: The APC was funded by authors

\section{Author Contributions:}

Safaa S. Hassan, Eman F. Mohamed ${ }^{4}$ and Dalia B Mohamed Mabrouk Salama and Eman F. Mohamed conceived and planned the experiments. Safaa S. Hassan planned and carried out the simulations. Safaa S. Hassan Elaria A Bedir, Abd El-Rahman M Hamza, Ahmed M Ahmed, Nouran M Ibrahim, Mahmoud S Abd El-Ghany, Nada N Sayed and Bassant M Eimera and Eman F. Mohamed to sample preparation. Safaa S. Hassan and Mabrouk Salama contributed to the interpretation of the results. Dalia B Mohamed planned the antidiabetic part with interpretation. Safaa S. Hassan, Dalia B Mohamed, Eman F. Mohamed and Mabrouk Salama took the lead in writing the manuscript. All authors participate in the biological studies. All authors provided critical feedback and helped shape the research, analysis and manuscript

Conflicts of Interest: The authors declare no conflict of interest. 